\title{
PENANGANAN PEREMPUAN KORBAN KEKERANAN SEKSUAL DI PPT SERUNI KOTA SEMARANG
}

\author{
Siti Nafisah \\ SMP Al-Hasyimiyyah Pangkalan Bun \\ e-mail: nafisah_91@yahoo.com
}

\begin{abstract}
Abstrak
Tulisan ini bertujuan: 1) Untuk mendeskripsikan bagaimana penanganan perempuan korban kekerasan seksual di PPT Seruni Kota Semarang; 2) Untuk menganalisa bagaimana penanganan perempuan korban kekerasan seksual di PPT Seruni Kota Semarang ditinjau dari perspektif bimbingan konseling Islam dengan fokus penelitian pada penanganan perempuan korban kekerasan seksual. Sumber data dalam penelitian ini adalah pengurus, konselor dan klien di PPT Seruni. Hasil penelitian menunjukkan PPT Seruni dalam menangani perempuan korban kekerasan seksual berbasis gender menggunakan beberapa tahapan, meliputi; konseling, pendampingan hukum, pendampingan medis, pendampingan psikologis, menyediakan rumah aman (shelter), melakukan penguatan ekonomi, dan mensosialisasikan hak-hak perempuan. Kedua, penanganan yang diberikan PPT Seruni relevan jika ditinjau dari fungsi Bimbingan Konseling Islam, yaitu: fungsi preventif (menjaga atau mencegah timbulnya masalah diri korban, contohnya dengan mengadakan sosialisasi dan penyuluhan hukum tentang hak-hak perempuan berbasis gender), kuratif (membantu korban dalam memecahkan masalah, contohnya melakukan konseling dan pendampingan yang diperlukan korban), presentatif (korban terjaga dari masalah, contohnya dengan adanya rumah aman atau shelterbagi korban), dan developmental (membantu individu memelihara dan mengembangkan situasi yang lebih baik, dengan melakukan penguatan ekonomi terhadap korban).
\end{abstract}

Kata Kunci: kekerasan seksual; PPT Seruni; Bimbingan Konseling Islam

\section{A. Pendahuluan}

Kekerasan telah memasuki berbagai wilayah komunitas: politik, ekonomi, sosial, budaya, seni, ideologi, pemikiran keagamaan, bahkan dalam wilayah sosial yang paling ekslusif yang bernama keluarga. Sangat ironis bahwa dalam masyarakat modern yang dibangun di atas prinsip rasio- 
nalitas, demokrasi, dan humanisasi, budaya kekerasan justru semakin menjadi fenomena kehidupan yang tak terpisahkan. Kekerasan sering dipandang sebagai fenomena sosial yang berada di luar dirinya, bukan menjadi masalah yang serius karena korban adalah perempuan yang memang lemah. Kenyataan ini diperkuat stereotype (pelabelan negatif) masyarakat bahwa perempuan dan anak adalah makhluk lemah, oleh karena itu kurang mampu mandiri, harus diatur, dipimpin, juga dididik. Sedangkan laki-laki adalah kuat, memimpin, mengatur, mendidik perempuan. Jika pelaku kekerasan perempuan dan korban adalah laki-laki, dianggap merupakan tindakan yang luar biasa. Masyarakat umumnya masih memandang kekerasan terhadap perempuan bukan sebuah masalah. Masyarakat lebih terbiasa dengan tradisi mentolerir kekerasan terhadap perempuan dan menganggapnya biasa-biasa saja karena belum sepenuhnya sensitif dalam mengenal masalah ini, bahwa telah terjadi kekerasan terhadap perempuan dan anak, sementara dampak negatifnya tidak pernah dijelaskan lebih mendalam dan diserap masyarakat lebih dini. ${ }^{1}$ Konsekuensi pandangan ini sangat jelas, bahwa peran-peran perempuan dalam dunia publik dan wilayah domestik menjadi tersubordinasi oleh laki-laki.

Pada tataran realitas sosial, pandangan ini sering dijadikan dasar bagi kaum laki-laki untuk melegitimasi tindakan superioritasnya, termasuk kekerasan terhadap kaum perempuan, baik dalam wilayah sosial, politik, ekonomi, ritual, maupun domestik. Selanjutnya cap subordinatif dan marginal segera dengan mudah ditimpakan kepada kaum perempuan. Misalnya, dikatakan bahwa secara kodrati tugas perempuan adalah di rumah, mengurus suami dan anak-anak, karena itu perempuan tidak berhak memimpin kaum laki-laki. Perempuan juga harus tunduk kepada kekuasaan laki-laki. Pada gilirannya, keyakinan ini juga akan melahirkan kekerasan dan penyiksaan terhadap perempuan secara fisik maupun mental. ${ }^{2}$

Sebagai umat muslim berkewajiban untuk berperan serta dalam menanggulangi permasalahan di atas, usaha tersebut dapat direalisasikan melalui aktivitas dakwah yang pada intinya adalah mengajak berbuat kebaikan dan mencegah kemungkaran serta mengajak kepada kebanaran.

${ }^{1}$ Mufidah, Psikologi Keluarga Islam Berwawasan Gender, (Yogyakarta: UIN-Malang Press, 2008), h. 273.

2Syafiq Hasyim, Menakar Harga Perempuan, (Bandung: Mizan, 1999), h. 205. 
Aktivitas dakwah yang dimaksud adalah sebagai usaha memberi bimbingan sekaligus konseling agar tetap sabar dan tawakal dalam menghadapi perjalanan hidup. Selain itu juga sebagai motivasi umat untuk selalu melakukan kebaikan supaya memperoleh kebahagiaan di dunia dan di akhirat. Salah satu realisasi dakwah dalam upanya menangai korban perkosaan dapat ditempuh melalui bimbingan dan konseling Islam. Dengan bimbingan dan konseling Islami diharapkan dapat membina klien sehingga klien pulih dari masalah yang dialaminya, dan klien dapat kembali ke lingkungan masyarakat serta dapat mengembangkan potensi yang ada pada dirinya sesuai dengan Al-Qur'an dan As-Sunnah serta mencegah klien dari prasangka buruk pada sesama manusia dan Tuhan-Nya.

Kekerasan terhadap Perempuan lebih singkatnya disebut (KtP) semakin mengemuka dengan menguatnya upaya yang berkaitan dengan keadilan dan kesetaraan gender. Kesetaraan terhadap perempuan seringkali disebut sebagai kekerasan berbasis gender, karena hal ini berawal dari subordinasi perempuan di masyarakat. Kekerasan terhadap Perempuan dapat merugikan aspek-aspek kesejahteraan fisik dan mental-emosional. Selain itu, KtP juga kalau kita cermati beresiko jangka panjang untuk terjadinya gangguan kesehatan lainnya. Berbagai akibat KtP, tentunya berakibat pada fisik, nonfisik, dan berpengaruh dalam bermasyarakat. ${ }^{3}$

Perempuan yang seharusnya berhak untuk menikmati dan memperoleh perlindungan terhadap hak-hak mereka, berbanding dengan realitanya yang sampai saat ini perempuan masih saja menjadi obyek kekerasan. Sistem hukum yang berlaku sekarang, baik dari segi substansi, aparat penegak hukum, maupun budaya hukum masyarakat, masih kurang responsif terhadap kepentingan perempuan, terutama dalam kasus-kasus kekerasan seksual yang menimpa kaum perempuan. Misalnya, KUHP sekarang tidak memadai lagi untuk menjangkau realitas kekerasan yang terjadi di masyarakat. Banyak bentuk kekerasan yang tidak tertampung dalam KUHP.

Legal Resources Center untuk Keadilan Gender dan Hak Asasi Manusia Jawa Tengah menyatakan terdapat ratusan kasus kekerasan terhadap perempuan tahun ini. Mulai awal hingga pertengahan 2014 tercatat 222

${ }^{3}$ Wibisono Wijono, "Kata Pengantar", Pedoman Pencegahan dan Penanganan Kekerasan terhadap Perempuan, (Jakarta: Bhakti Husada, 2001). 
kasus dengan korban berjumlah 386 perempuan. Jumlah pelaku kekerasannya sebanyak 365 orang. Berdasarkan jenisnya, 83 kasus masuk kategori KDRT dengan 83 perempuan menjadi korban. Sedangkan 65 kasus berupa perkosaan dengan 77 korban, 30 kasus prostitusi dengan 157 korban, 28 kasus KDP dengan 52 korban, 9 kasus trafficking dengan 17 korban, 6 kasus buruh migran dengan 6 korban. ${ }^{4}$

Di kota Semarang terdapat Pusat Pelayanan Terpadu (PPT), sebagai wadah penyelesaian persoalan kekerasan perempuan dan anak berbasis gender yakni PPT Seruni. Tugasnya adalah turut membantu dalam upaya pemulihan kepada perempuan dan anak korban kekerasan seperti kekerasan dalam rumah tangga (KDRT), kekerasan dalam pacaran (KDP), kekerasan terhadap anak (KTA), perkosaan, pelecehan seksual, dan perdagangan orang. PPT Seruni berusaha memberikan layanan kepada klien melalui bimbingan fisik, psikis, sosial, dan latihan keterampilan.

Data dari PPT Seruni tentang kekerasan seksual terhadap perempuan di tahun 2013 sebanyak 8 kasus yang ditangani, diantaranya 4 kasus perkosaan dan 4 kasus pelecehan seksual. Dan pada tahun 2014 kasus kekerasan seksual yang ditangani sebanyak 13 kasus, diantaranya 3 kasus perkosaan dan 10 kasus pelecehan seksual. Dari data tersebut menunjukkan bahwa kekerasan seksual terhadap perempuan di kota Semarang mengalami peningkatan. PPT Seruni dalam menangani korban kekerasan seksual bersifat holistik bantuan layanan merupakan suatu paduan multi-disiplin (hukum, medis, psikologis). Bekerjasama dengan tokoh agama, penanganan spiritual juga diberikan kepada perempuan korban kekerasan seksual agar mereka mendapat ketenangan batin dan membantu mengembalikan kondisi psikologisnya kepada kondisi yang lebih baik. Selain itu, PPT Seruni memberikan layanan rumah aman (shelter) bagi korban yang terancam jiwanya.

\section{B. Pembahasan}

Masalah kekerasan terhadap perempuan merupakan masalah yang kompleks, karena akar persoalannya ada pada budaya yang telah ditanamkan selama berabad-abad. Sementara itu, masih banyak orang yang tidak

\footnotetext{
${ }^{4}$ http://www.tempo.co/read/news/2014/08/04/063597024/Kekerasan-terhadapPerempuan-di-Jateng-10-Tewas diakses tanggal 02 November 2014.
} 
peduli terhadap kekerasan yang berbasis gender tersebut, khususnya kekerasan seksual. Mereka masih menganggap bahwa kekerasan seksual merupakan sesuatu yang biasa dialami oleh seseorang terutama perempuan. Istilah "kekerasan" dalam Kamus Besar Bahasa Indonesia diartikan: "perbuatan seseorang atau sekelompok orang yang menyebabkan cedera atau matinya orang lain atau menyebabkan kerusakan fisik atau barang orang lain. Kekerasan terhadap perempuan mencakup semua tindakan berdasarkan perbedaan jenis kelamin yang berakibat, atau mungkin berakibat, kesengsaraan atau penderitaan perempuan secara fisik, seksual, dan psikologis, termasuk ancaman tindakan tertentu, pemaksaan atau perampasan kemrdekaan secara sewenang-wrnang, baik yang terjadi di depan umum maupun dalam kehidupan pribadi. ${ }^{5}$

Kekerasan yang sering terjadi di masyarakat yaitu kekerasan berbasis gender, merupakan jenis kekerasan yang dilakukan oleh seseorang terhadap jenis kelamin yang berbeda seperti laki-laki melakukan tindak kekerasan terhadap perempuan atau sebaliknya, namun biasanya perempuan lebih banyak menjadi korban daripada menjadi pelaku. Faktor penyebab perempuan lebih dominan menjadi korban antara lain disebabkan terjadinya diskriminasi gender ${ }^{6}$.Dalam Deklarasi yang disahkan oleh PBB pada tahun 1993, yaitu Deklarasi Penghapusan Kekerasan terhadap Perempuan pasal 1, yang berbunyi: "Kekerasan terhadap perempuan adalah segala bentuk tindakan kekerasan yang berbasis gender, yang mengakibatkan atau akan mengakibatkan rasa sakit atau penderitaan terhadap perempuan, termasuk ancaman, paksaan, pembatasan kebebasan, baik yang terjadi di area publik maupun domestik" 7

Dalam hampir semua kelompok masyarakat, terdapat pembedaan tugas dan peran sosial atas laki-laki dan perempuan. Semata-mata karena alasan, bahwa hal itu lebih pantas (secara sosial-budaya) bagi jenis kelamin tertentu. Tidak dapat dipungkiri bahwa laki-laki maupun perempuan diberi label-label (storeotype) tertentu berkaitan dengan peran gender mereka, seperti "laki-laki gagah perkasa", "perempuan lembut manja", dan sebagainya.

${ }^{5}$ Siti Musdah Mulia, Muslimah Reformis: Perempuan Pembaru Keagamaan, (Bandung: Mizan Pustaka, 2004), h. 154.

${ }^{6}$ Ibid., h. 267.

${ }^{7}$ Ibid., h. 155. 
Citra ini dipertajam melalui berbagai media, sehingga ada keyakinan bahwa memang demikianlah kodrat laki-laki dan perempuan, termasuk keyakinan bahwa perempuan adalah makhluk yang lemah dan sebaliknya laki-laki adalah makhluk yang kuat. Atau, keyakinan bahwa perempuan itu "seksi" dan laki-laki itu "macho". Karena didukung oleh sistem dan struktur sosial budaya yanng bersifat "maskulin" (karena lebih mendukung dan menguntungkan bagi laki-laki ketimbang perempuan), maka jadilah perempuan sebagai "obyek" atau sasaran dari berbagai tindak kesewenangan-wenangan, baik di dalam rumah, di masyarakat, di sekolah, dan sebagainya. ${ }^{8} \mathrm{Ke}-$ kerasan seksual adalah segala macam bentuk perilaku yang berkonotasi seksual yang dilakukan sepihak dan tidak diinginkan oleh orang yang menjadi sasaran. Kekerasan seksual mencakup pelecehan seksual sampai memaksa untuk melakukan hubungan seksual tanpa persetujuan korban atau melakukan hubungan seksual dengan cara-cara tidak wajar atau tidak disukai korban. ${ }^{9}$

Kekerasan seksual terhadap perempuan memiliki dua arti. Pertama, secara umum, sebagai kekerasan berdasar gender atau gender based violence. Kekerasan seksual terhadap perempuan sebagai kekerasan berdasar gender (gender based violence), secara luas diartikan sebagai tindakan yang mengakibatkan atau mungkin mengakibatkan kesengsaraan atau penderitaan bagi perempuan secara fisik, seksual dan psikis, termasuk ancaman tindakan tertentu, pemaksaan atau perampasan kemerdekaan secara sewenangwenang yang dilakukan di depan umum atau di dalam kehidupan pribadi.

Tergolong kekerasan jenis ini adalah pemukulan, pelecehan seksual terhadap perempuan kanak-kanak, kekerasan terkait maskawin, pemerkosaan dalam perkawinan,pengrusakan alat kelamin, praktik-praktik tradisi yang menyiksa dan mencederai tubuh dan kelamin, pemerkosaan, pelecehan, dan ancaman seksual di sektor publik, perdagangan perempuan, dan pelacuran paksa. Demikian juga kekerasan-kekerasan lain terhadap perempuan yang berkembang di/atau kembangkan oleh lingkungan domestik (keluarga), masyarakat, ataupun negara.

\footnotetext{
${ }^{8}$ Hayati, Ibid, hlm. 37

${ }^{9}$ Sri Suhandjati Sukri, Islam menentang Kekerasan Terhadap Istri, (Yogyakarta: Gama Media, 2004), h. 9.
} 
Kedua, secara khusus, sebagai bentuk tertentu dari kekerasan tehadap perempuan, yaitu kekerasan berdasar gender yang mengakibatkan kesengsaraan atau penderitaan pada perempuan secara seksual. Kerap diartikan sebagai tindak kejahatan yang khusus menyerang organ seksual perempuan, berupa pemaksaan hubungan seksual (pemerkosaan), pelecehan seksual, atau pengrusakan alat reproduksi.

Kekerasan seksual terhadap perempuan merupakan ragam dan kelanjutan kekerasan berdasar gender. Kekerasan berdasar gender menyudutkan kemanusiaan perempuan ke titik nadir. Ia tak lagi subyek, tetapi semata obyek, termasuk dari beragam kekuasaan dan kekerasan (politik, ekonomi, sosial, dan seksual). Berabad-abad lamanya kekerasan secara sistematik menimpa perempuan walaupun ia belum menjadi sesuatu yang dikenal namanya. Istilah kekerasan terhadap perempuan (violence against women) dikenal dan digunakan khalayak umum akhir-akhir ini saja, yakni setelah dampak kekerasan tersebut mulai dirasakan secara luas..$^{10}$

Terdapat banyak jenis kekerasan. Jenis kekerasan terhadap perempuan meliputi kekerasan fisik, psikologis, ekonomi, seksual, dan pemaksaan atau perampasan kemerdekaan. Termasuk dalam kekerasan fisik adalah perbuatan yang mengakibatkan rasa sakit, cedera, luka, atau cacat tubuh yang menyebabkan kematian ataupun tidak. Bentuk kekerasan fisik antara lain memukul, menendang, menempeleng, menjambak rambut dan sebagainya. Dan bentuk kekerasan seperti ini yang kerap kali terjadi pada kekerasan terhadap perempuan berbasis gender. Kekerasan Psikis, Kekerasan yang tidak tampak bukti yang dapat dilihat secara kasat mata adalah kekerasan psikis. Kekerasan psikis sering menimbulkan dampak yang lebih lama, lebih dalam dan memerlukan rehabilitasi secara intensif. Bentuk kekerasan psikis antara lain berupa ungkapan verbal, sikap atau tindakan seperti berteriak-teriak, mengancam, menguntit, memata-matai serta tindakan lain yang tidak menyenangkan yang menyebabkan seorang korbannya merasa tertekan, ketakutan, merasa bersalah, depresi, trauma, hilangnya rasa percaya diri, kehilangan masa depan, timbulnya rasa tidak berdaya, bahkan ingin bunuh diri. Pada pasal 7 kekerasan psikis sebagaimana dimaksud dalam pasal 5 huruf $b$ adalah perbuatan yang mengakibatkan

\footnotetext{
${ }^{10}$ Marlia, Milda, Marital Rape Kekerasan Seksual Terhadap Istri, (Yogyakarta: Pustaka Pesantren, 2007), h. 16-19.
} 
ketakutan, hilangnya rasa percaya diri, hilangnya kemampuan untuk bertindak, rasa tidak berdaya, dan penderitaan psikis berat pada seseorang ${ }^{11}$

Kekerasan ekonomi adalah setiap perbuatan yang membatasi seseorang untuk bekerja, baik di dalam maupun di luar rumah, yang menghasilkan uang/barang atau tindakan yang dengan sengaja mengeksploitasi perempuan untuk dapat memenuhi kebutuhan ekonomi. Termasuk bentuk kekerasan ekonomi adalah mengambil uang korban, mengawasi pengeluaran uang sampai sekecil-kecilnya dengan tujuan agar dapat mengendalikan korban. Dalam hal ini biasanya terjadi pada rumah tangga yang perempuannya mengalami peran ganda. Disisi lain ada ketergantungan ekonomi istri pada suami karena istri tidak bekerja. Misalnya suami enggan membantu menyelesaikan pekerjaan rumah tangga istri, suami tidak memberikan nafkah istri, dan sebagainya. Pemaksaan atau Perampasan Kemerdekaan dengan sewenang-wenang meliputi perbuatan yang mengakibatkan seseorang terisolasi dari lingkungan sosialnya, seperti larangan berkomunikasi dengan orang lain. Termasuk perampasan kemerdekaan adalah merendahkan keyakinan dan kepercayaan korban atau memaksa korban mempraktikkan ritual ataupun keyakinan tertentu.

Kekerasan seksual adalah segala macam bentuk perilaku yang berkonotasi seksual yang dilakukan sepihak dan tidak diinginkan oleh orang yang menjadi sasaran. Kekerasan seksual mencakup pelecehan seksual sampai memaksa untuk melakukan hubungan seksual tanpa persetujuan korban atau melakukan hubungan seksual dengan cara-cara tidak wajar atau tidak disukai korban, atau menjauhkannya dari kebutuhan seksualnya. Bentuk-bentuk kekerasan seksual adalah menyentuh, meraba, mencium, memaksa korban melihat pornografi, gurauan seksual yang tidak dikehendaki korban, ucapan yang merendahkan, melecehkan, atau menyakiti korban. Kekerasan seksual ini dapat dialami oleh laki-laki maupun perempuan. ${ }^{12}$ Kekerasan terhadap perempuan secara seksual menurut Skaine disebabkan oleh kecenderungan kaum laki-laki dalam menempatkan diri sebagai kelompok dominan yang mengendalikan seksualitas dan identitas gender perempuan. Oleh karena itu, kaum laki-laki

${ }^{11}$ Mufidah, Psikologi Keluarga Islam Berwawasan Gender, h. 271.

${ }^{12}$ Sri Suhandjati Sukri, Islam menentang Kekerasan Terhadap Istri, h. 7-9. 
memberlakukan mekanisme kontrol terhadap perempuan yang disebut sebagai sexual terrorism, yakni sistem ideologi yang diberlakukan oleh lakilaki terhadap perempuan dalam rangka mendominasi dan mengontrol perempuan yang termanifestasikan melalui kekerasan.

Laporan organisasi internasional hak asasi manusia menyebutkan bahwa kekerasan yang ditimpakan kepada kaum perempuan biasanya digunakan sebagai sarana untuk melakukan tekanan politik terhadap kekuatan lawan politik mereka. Di samping itu, ada beberapa negara yang memperkerjakan perempuan dalam pengaturan kondisi seksual dan menerima mereka untuk mengandung dan melahirkan. ${ }^{13}$ Menurut Kalyanamitra dan Prasetyo (Saptiawan, 2010: 204), dalam intensitas yang paling ringan, kekerasan seksual disebut sebagai pelecehan seksual. Bentuk pelecehan seksual dapat berupa siulan nakal, kerdipan mata, gurauan dan olok-olok yang menjurus pada seks, memandangi tubuh mulai ujung rambut sampai ujung kaki, pernyataan mengenai tubuh atau penampilan fisik, memberikan bahasa isyarat yang berkonotasi seksual, memperlihatkan gambar-gambar porno, memperlihatkan organ seks, mencolek, serta meraba atau mencubit. ${ }^{14}$

\section{Bentuk Kekerasan terhadap Perempuan}

Bentuk kekerasan terhadap perempuan secara umum dapat dikelompokkan ke dalam dua kategori: kekerasan di ranah domestik (dalam rumah tangga) dan kekerasan di ranah publik (di luar rumah tangga)

\section{Kekerasan dalam Rumah Tangga}

Kekerasan dalam rumah tangga atau disingkat KDRT atau disebut juga kekerasan domestik adalah penganiayaan yang dilakukan oleh seseorang yang berada dalam satu keluarga terhadap anggota keluarga lain. KDRT dapat berbentuk: 1) penganiayaan fisik (seperti pukulan, tendangan); 2) penganiayaan psikis atau emosional (seperti ancaman, hinaan, cemoohan); 3) penganiayaan seksual (pemaksaan hubungan seksual). Kekerasan

\footnotetext{
${ }^{13}$ Muhammad Haitsam al-Khayyath, Problematika Muslimah di Era Modern, (Jakarta: Erlangga, 2007), h. 96.

${ }^{14}$ Saptiawan, Sugihastuti Itsan Hadi, Gender dan Inferioritas Perempuan, (Yogyakarta: Pustaka Pelajar, 2010, h. 204.
} 
seksual sebagaimana dimaksud dalam pasal 5 huruf c meliputi: 1). Pemaksaan hubungan seksual yang dilakukan terhadap orang yang menetap dalam lingkup rumah tangga tersebut; 2). Pemaksaan hubungan seksual terhadap salah seorang dalam lingkup rumah tangganya dengan orang lain untuk tujuan komersial dan/atau tujuan tertentu.

KDRT dapat menimpa siapa saja di dalam rumah tangga, termasuk ibu, istri, suami, bapak, anak atau bahkan pembantu rumah tangga. Namun dalam banyak literatur, KDRT lebih dipersempit artinya yaitu mencakup penganiayaan suami terhadap istrinya. Salah satu penyebab terjadinya KDRT adalah karena Pemahaman masyarakat yang hanya memahami secara tekstual bukan kontekstual terhadap ajaran agama mengenai aturan mendidik istri. Kepatuhan istri hanya terhadap suami, penghormatan hanya ditujukan untuk suami. Sehingga laki-laki diperbolehkan menguasai perempuan. Adapun hadits yang sering dijadikan pedoman laki-laki untuk menjadikan dirinya penghormatan terhadap istrinya

$$
\text { ان عن عا عشة ان رسول اللة صلى اللة علة و سلم قال: ثم لو ا مرت احد ا }
$$

Dari Aisyah berkata bahwa Rasul bersabda "jika aku diperbolehkan untuk memerintah manusia sujud kepada manusia lainnya maka sungguh aku akan menyuruh wanita agar bersujud kepada suaminya" (Qozwaini, Juz 1: 595).

Hadis lain yang sering dijadikan sebagai legitimasi terhadap pemaksaan, penindasan, dan bahkan tindak KDRT terhadap perempun adalah Hadits riwayat al Bukhari:

$$
\begin{aligned}
& \text { عن ابى هر ره عن النبى صلى اللة علة و سلم قال: ثم اذا باتت المر اة }
\end{aligned}
$$

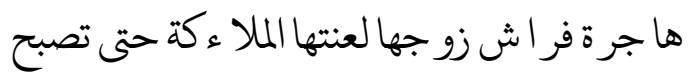

Dari Abu Hurairah berkata bahwa Rasulullah bersabda "ketika seorang wanita (istri) tidur meninggalkan tempat tidur suaminya, maka ia di laknat malaikat sampai pagi hari" (Naisaburi, juz 1: 1059).

Yang lebih menyedihkan, ada anggapan di kalangan masyarakat yang memandang persoalan ini sebagai masalah internal keluarga yang tidak 
memerlukan campur tangan pihak lain. Budaya masyarakat seperti ini langsung maupun tidak langsung membenarkan adanya pertengkaran dalam rumah tangga. Malah banyak yang menganggap sebagai bungabunga rumah tangga. Akibatnya, KDRT menjadi sesuatu yang lumrah di masyarakat.

\section{Kekerasan dalam Ruang Publik}

Kekerasan jenis ini sebetulnya sama saja dengan bentuk KDRT, hanya saja bentuk yang satu ini terjadi di runag publik (di luar rumah tangga), seperti di tempat kerja, lembaga-lembaga pendidikan, tempat-tempat hiburan, di dalam angkutan umum, dan di jalanan. Penyebab utamanya adalah relasi kekuasaan yang timpang, baik yang didasarkan pada kedudukan/ jabatan, kekayaan, pendidikan, ataupun yang didasarkan pada budaya atau ideologi gender. Faktor-faktor penyebab lainnya adalah potensi pribadi, peniruan dari media masa, kesalahan pola asuh, dan frustasi. Akan tetapi, faktor-faktor tersebut hanyalah faktor pemicu yang tidak akan meledak kalau tidak ada kondisi relasi laki-laki dan perempuan yang timpang.

Sebagaimana halnya KDRT, kekerasan di ruang publik dapat berbentuk: 1) penganiayaan fisik (seperti pukulan, benturan, tendangan); 2) penganiayaan psikis atau emosional (seperti ancaman, hinaan, cemoohan); dan 3) penganiayaan seksual (perkosaan dan berbagai bentuk pelecehan seksual, perdagangan perempuan dan pelacuran paksa). Terdapat banyak modus kekerasan terhadap perempuan, tetapi yang paling sering disosialisasikan lewat media-media televisi, seperti dalam pertunjukkan sinetron-sinetron di Indonesia, adalah kekejaman mertua terhadap menantu atau sebaliknya, kelicikan suami terhadap istri atau sebaliknya, dan segala bentuk perselingkuhan. Semua itu membuat masyarakat semakin terbiasa dengan tindak kekerasan. ${ }^{15}$

Bentuk kekerasan seksual terutama tindakan pencabulan dan pemerkosaan, sulit untuk diproses hukum karena biasanya tindakan dilakukan di luar sepengetahuan orang, sehingga mengalami hambatan ketika menghadirkan saksi maupun penyediaan alat bukti. Alat bukti sesungguhnya dapat ditemukan pada bekas pakaian, rambut atau lainnya, sering tidak

${ }^{15}$ Siti Musdah Mulia, Muslimah Reformis: Perempuan Pembaru Keagamaan, h. 155-157. 
dapat digunakan lagi karena kecenderungan korban berusaha segera membersihkan dan membuangnya. Satu-satunya alat bukti yang digunakan oleh pihak penyidik adalah visum et repertum dengan standar yang telah ditentukan. Jika bukti visum tidak masuk pada standar tersebut mengalami kesulitan dalam proses penyidikan. kekerasan seksual dalam rumah tangga juga sering terjadi tetapi korban tidak berani melapor karena adanya ikatan perkawinan, atau ikatan emosional dan sosial lainnya sehingga sulit untuk diungkap kecuali korban berani berbicara dan melaporkan kasusnya. ${ }^{16}$

Bentuk kekerasan lainnya yaitu incest, adalah kekerasan seksual yang terjadi antar anggota keluarga. Pelaku biasanya adalah anggota keluarga yang lebih dewasa dan korban adalah anak-anak. Bentuk kekerasan seksual yang termasuk dalam kategori ini adalah yang terberat, karena pertimbangan:

a. Bahwa pelaku adalah orang dekat atau keluarga sendiri, sehingga antara korban dan pelaku sangat mungkin untuk selalu saling bertemu satu sama lain dengan seolah-olah tidak pernah terjadi apa-apa di antara keduanya.

b. Biasanya incest ini terjadi secara berulang, karena bagi korban, dirinya terjebak dalam dilema, yaitu di satu sisi takut dengan ancaman pelaku, dan di sisi lain ada perasaan khawatir bila bercerita kepada anggota keluarga yang lain ia tidak akan dipercaya.

Korban incest biasanya adalah anak-anak, karena biasanya korban perkosaan incest terjadi tanpa ada perlawanan yang berarti dan relatif jarang menimbulkan trauma fisik, karena biasanya anak-anak cenderung menyerah tanpa melawan (karena tidak memahami apa yang terjadi pada dirinya). Sedangkan pelaku kekerasan, biasanya melakukan dengan menggunakan bujukan akan memberi imbalan tertentu, seperti jajanan, permen, atau uang sehingga anak merasa senang. Selain itu, faktor penyebab anak-anak ini menyerah begitu saja adalah, karena pelaku biasanya adalah orang yang mereka percayai atau mereka sayangi (telah mereka kenal secara cukup dekat).

Tragisnya, masalah ini masih belum mendapat pengakuan sebagai problem, karena masyarakat lebih berkeyakinan bahwa posisi laki-laki

${ }^{16}$ Ibid, h. 270. 
adalah figur yang "punya kekuasaan" atas istrinya. Bentuk kekerasan seksual dalam perkawinan antara lain dipaksa melakukan hubungan seks dengan cara-cara yang tidak dikehendaki istri (oral, anal, dan berbagai cara lain yang tidak disukai istri). Pada umumnya negara tidak mengakui hal semacam ini sebagai bentuk perkosaan (karena seks adalah hak suami), sehingga biasanya para istri memilih diam dan menyalahkan dirinya sendri, serta mencoba menerima itu semua sebagai ujian untuk menjadi istri yang baik. ${ }^{17}$ Apabila kekerasan seksual terhadap gadis-gadis dan anak-anak perempuan ini sering terjadi, adalah hal yang lumrah bila cara-cara yang diperlukan untuk menyembunyikan kehilangan keperawanan akan dilakukan sebisa mungkin. Cara-cara tersebut bisa jadi dengan mengoperasi selaput dara atau membuat tiruan darah yang keluar pada saat penetrasi.

Melihat kerugian yang harus diderita oleh korban kekerasan seksual tersebut, yang pada akhirnya juga akan merugikan masyarakat pada umumnya, kasus kekerasan seksual seperti perkosaan, harus menjadi perhatian kita semua. Seseorang yang mengalami korban kejahatan tersebut sangat menderita tekanan, baik lahir ataupun batin. Dan tidak jarang, si korban tersebut ada pula yang mengalami pembunuhan atau penganiyaan oleh si pelaku. Untuk membantu perempuan korban kekerasan ini, seorang konselor harus memahami prinsip dasar bekerja untuk mendampingi mereka, yaitu:

a. Perempuan korban kekerasan janganlah dipersalahkan atas kejadian yang menimpanya.

b. Pelaku kekerasan adalah orang yang seharusnya bertanggung jawab atas tindak kekerasan yang telah dilakukannya. ${ }^{18}$

c. Masyarakat dan berbagai institusi pemerintah dan non pemerintah adalah pihak yang bertanggung jawab secara tidak langsung atas masalah kekerasan terhadap perempuaan.

d. Solusi atas masalah kekerasan terletak pada kombinasi antara aksi pribadi dan sosial, serta didukung oleh sistem hukum yang memadai.

e. Tujuan bekerja membantu perempuan korban kekerasan adalah membantu mereka membuat keputusan sendiri, dan agar selanjutnya ia menjadi lebih mandiri. ${ }^{19}$

\footnotetext{
${ }^{17}$ Elli Nur Hayati, Panduan untuk Pendamping Perempuan Korban Kekerasan (Konseling Berwawasan Gender), (Yogyakarta: Pustaka Pelajar, 2000), h. 38.

${ }^{18}$ Wawancara Bu Irni, 29 Agustus 2014.
} 


\section{Penanganan Kekerasan terhadap Perempuan}

PPT Seruni di dalam menangani kasus perempuan korban kekerasan seksual menggunakan beberapa metode, metode tersebut adalah:

1. Pelayanan Hotline Service 24 jam bagi para korban. Pelayanan Hotline Service 24 jam melibatkan sejumlah relawan dan pengurus service hotline berupa telepon kantor handphone, SMS dan E-mail. Hotline dibuka bagi para korban kekerasan yang hendak berkonsultasi dan menerima konseling atau mengadukan kasus yang dialaminya. Membuka konsultasi melalui media massa (radio dan surat kabar) dan melakukan investigasi kasus kekerasan yang dialami korban secara menyeluruh agar kasus yang dialami korban terselesaikan dengan baik bagi korban dan tidak terjadi lagi kekerasan terhadap perempuan.

2. Pendampingan Litigasi dan Non Litigasi. Masih lemahnya perlindungan dan penegakan hukum bagi perempuan serta sikap yang tidak responsif dari aparat penegak hukumnya sendiri (Polisi, Jaksa, dan Hakim). Namun yang memprihatinkan adalah masih minimnya kesadaran perempuan sendiri atas hak-haknya serta terbatasnya akses informasi mengenai institusi lembaga yang bisa membantu dalam penanganan kasusnya, sehingga upaya-upaya pembelaan terhadap perempuan dalam kasus kekerasan seksual menjadi mutlak perlu.

3. Pembelaan (advokasi) baik yang melalui jalur hukum (litigasi) maupun non hukum (non litigasi) akan dilakukan dengan harapan akan menjadi sebuah tindakan aksi yang merupakan manifestasi atas hak-haknya untuk diperlukan secara adil sebagai manusia yang merdeka dan bermartabat. Bentuk kegiatan program ini adalah pembelaan hukum, membangun jaringan kerja penanganan kasus dan pengorganisasian basis-basis komunitas (Standart Oprasional Pelayanan (SOP) Seruni). ${ }^{20}$

\section{Program Penanganan}

Pusat Pelayanan Terpadu (PPT) Seruni Kota Semarang dalam menangani kasus perempuan korban kekerasan seksual mempunyai beberapa program penanganan agar keberhasilan tercapai dengan sukses, yaitu dengan penanganan tahap awal dan lanjutan:

${ }^{19}$ Elli Nur Hayati, Panduan untuk Pendamping Perempuan Korban Kekerasan ...., h. 54.

${ }^{20}$ Dokumen PTT Seruni. 
a. Program Penanganan Tahap Awal Bagi Korban. Secara empirik, kasus-kasus perempuan korban kekerasan seksual dapat terungkap setelah adanya informasi berupa laporan dari masyarakat atau pengaduan dari keluarga atau para korban sendiri. Mengingat perlunya korban segera mendapatkan pertolongan darurat medis berupa pelayanan pemeriksaan medis dan proses pengobatan kalau diperlukan. Maka optimalisasi dalam hal penanganan tersebut menjadi signifikan. Sasaran program ini adalah perempuan (tanpa diskriminasi apapun) yang mengalami tindak kekerasan. Bentuk kegiatan yang dilakukan adalah penanganan korban oleh Seruni dan jika dibutuhkan penanganan lebih lanjut secara Visum et repertum dilakukan oleh tenaga profesional medis yang dirujuk ke RSUD Ketileng.

b. Program Penanganan Tahap Lanjut. Penanganan terhadap korban tidak seketika berhenti meski telah ada proses medis dan yuridis yang ditempuh maka dilanjutkan bantuan terapi intensif dalam kurun waktu tertentu tergantung derajat traumatis yang dialami korban. Upaya terapi pasca traumatis penting di dalam proses penyembuhan dan pemulihan korban. Progam ini terdiri dari dua kegiatan yakni: penanganan pasca traumatis secara psikoterapi dan penanganan pasca traumatis secara medico psikososial oleh tenaga-tenaga ahli seperti psikolog, psikiater, dan rohaniawan. Pada saat yang sama dilakukan kegiatan penyediaan rumah sementara (rumah aman/shelter) (Standar Oprasional Pelayanan (SOP) Seruni).

\section{Pendampingan dan Pelayanan Konseling}

PPT Seruni dalam memberikan pendampingan terhadap perempuan korban kekerasan seksual menggunakan beberapa pendampingan, yaitu:

a. Pendampingan Selama Proses Hukum. Bantuan atau pendampingan hukum diberikan mulai dari tingkat kepolisian sampai ke pengadilan. Pendampingan dilakukan dalam setiap tahapan proses hukum untuk memastikan terpenuhinya hak-hak korban.

b. Pendampingan Medis. Pelayanan medis diberikan kepada korban karena mereka mengalami kekerasan fisik dengan cara Visum et repertum atau mengalami gangguan psikis dari dampak perkosaan, seperti korban mengalami depresi, trauma dan tekanan psikologis lainnya. 
c. Pendampingan Psikologis. Diberikan penanganan secara psikoterapi dengan tujuan untuk membantu dalam pemulihan pasca traumatis. Terapi pasca traumatis penting di dalam proses penyembuhan dan pemulihan perempuan korban kekerasan seksual karena akan membantu perkembangan psikis korban ke arah yang lebih baik.

d. Pendampingan Spiritual. Pendampingan spiritual diberikan kepada perempuan korban kekerasan seksual supaya mereka mendapat ketenangan batin dan membantu mempercepat proses penyembuhan traumatis. Ibu Dewi selaku pengurus PPT Seruni Kota Semarang mengatakan:

"Untuk pendampingan spiritual agama Islam dari pihak seruni sendiri tidak menyediakan, Apabila dari pihak korban menginginkan pemdampingan spiritual agama Islam PPT Seruni juga bekerjasama dengan Pemkot yang akan ditangani langsung oleh Ibu Fatimah Usman Masykur" (Wawancara Bu Irni, 29 Agustus 2014).

e. Rumah Aman (Shelter). Untuk korban kekerasan yang terancam keselamatan jiwanya dan membutuhkan tempat tinggal sementara secara rahasia disediakan rumah aman (shelter). Klien yang ada di shelter diberikan kegiatan rehabilitatif, yaitu berupa konseling yang secara continue dilakukan oleh pendamping. Selain itu, juga diadakan pelatihan-pelatihan, kegiatan yang bersifat rekreatif-edukatif, yang bertujuan untuk menghilangkan kejenuhan, kepenatan serta kesedihan korban sehingga perempuan korban kekerasan seksual termotivasi untuk terus optimis dalam merencanakan masa depannya. ${ }^{21}$

\section{E. Kesimpulan}

Proses penanganan perempuan korban kekerasan seksual di Pusat Pelayanan Terpadu Seruni Kota Semarang meliputi: Pertama, konseling. Dilakukan untuk mengetahui permasalahan yang dialami korban, sebagai sarana untuk menguatkan kondisi psikis korban/klien. Penguatan dan pengendalian potensi diri korban untuk memunculkan kekuatan dari dalam diri individu klien untuk dapat bangkit dari keterpurukan yang dialami klien. Kedua, pendampingan hukum. Bantuan atau pendampingan hukum

${ }^{21}$ Wawancara Bu Ninik, tanggal 03 September 2014. 
diberikan mulai dari tingkat kepolisian sampai kepengadilan. Pendampingan dilakukan dalam setiap tahapan proses hukum untuk memastikan terpenuhinya hak-hak korban. Ketiga, pendampingan medis. Diberikan kepada korban karena mereka mengalami kekerasan fisik atau mengalami gangguan psikis dari dampak perkosaan, seperti korban mengalami depresi, trauma dan tekanan psikologis lainnya. Keempat, menyediakan rumah aman (shelter). Tempat perlindungan bagi perempuan korban kekerasan seksual yang secara darurat berada dalam ancaman atau situasi yang mengancam keselamatan jiwa korban dan harus membutuhkan tempat sementara. Kelima, melakukan penguatan ekonomi. Penguatan ekonomi terhadap korban merupakan salah satu hal yang penting karena korban sangat membutuhkan hal yang demikian untuk bersikap mandiri dan tidak menggantungkan hidup kepada pihak lain. Keenam, mensosialisasikan hakhak perempuan. Langkah mensosialisasikan hak-hak perempuan yang sesuai dengan hukum negara dan agama diharapkan mengurangi masalahmasalah kekerasan terhadap perempuan.]

\section{Daftar Pustaka}

Dokumen PTT Seruni

Elli Nurhayati, Panduan untuk Pendamping Perempuan Korban Kekerasan (Konseling Berwawasan Gender), Yogyakarta: Pustaka Pelajar, 2000.

Hasyim, Syafiq, Menakar Harga Perempuan, Bandung: Mizan, 1999.

al-Khayyath, Muhammad Haitsam, Problematika Muslimah di Era Modern, Jakarta: Erlangga, 2007.

Marlia, Milda, Marital Rape Kekerasan Seksual terhadap Istri, Yogyakarta: Pustaka Pesantren, 2007.

Mufidah, Psikologi Keluarga Islam Berwawasan Gender, Yogyakarta: UIN-Malang Press, 2008.

Mulia,Siti Musdah, Muslimah Reformis: Perempuan Pembaru Keagamaan, Bandung: Mizan Pustaka, 2004.

Saptiawan, Sugihastuti Itsan Hadi, Gender dan Inferioritas Perempuan, Yogyakarta: Pustaka Pelajar, 2010. 
Sukri, Sri Suhandjati, Islam Menentang Kekerasan terhadap Istri, Yogyakarta: Gama Media, 2004.

Wijono, Wibisono, "Kata Pengantar", Pedoman Pencegahan dan Penanganan Kekerasan terhadap Perempuan, Jakarta: Bhakti Husada, 2001.

Wawancara Bu Irni, 29 Agustus 2014

Wawancara Bu Ninik, tanggal 03 September 2014.

Wawancara dengan Helen Intania (Kabid Internal), 27 Juni 2014.

Wawancara dengan Dian Puspitasari (Divisi Bantuan Hukum dan Konseling), 21 Mei 2015.

http://www.tempo.co/read/news/2014/08/04/063597024/Kekerasanterhadap-Perempuan-di-Jateng-10-Tewas Diakses tanggal 02 November 2014. 